\title{
チタン合金製弁ばねの開発*
}

\author{
薮下毅士 ${ }^{* *}$ ，高村典利 ${ }^{* *}$ ，丹下 彰 ${ }^{* *}$
}

\section{Development of Valve Spring Made of Titanium Alloy}

\author{
Takeshi YABUSHITA, Noritoshi TAKAMURA and Akira TANGE
}

\begin{abstract}
We have investigated the influence of aging conditions on fatigue strength of titanium alloy and studied the wear resistant coatings for titanium alloy. Utilizing the results, we have developed the valve spring made of titanium alloy in order to increase engine speed and lighten engine weight.

The main results obtained are summarized as follows:

1) Tensile strength dependence of fatigue strength in Ti-13V-11Cr-3Al alloy is opposite to tensile strength dependence in steel.

2) Settling performance of Ti-13V-11Cr-3Al alloy is improved as increasing tensile strength, and settling performance is equivalent to steel with higher strength.

3) $\mathrm{Ni}-\mathrm{P}$ electroless plating and $\mathrm{Ni}-\mathrm{P}+\mathrm{Au}-\mathrm{Ni}$ electroless plating are excellent methods as wear resistant coating for titanium alloy.

4) Ti-13V-11Cr-3Al alloy springs with optimum tensile strength and coating by Ni-P electroless plating or $\mathrm{Ni}-\mathrm{P}+\mathrm{Au}-\mathrm{Ni}$ electroless plating pass the motoring test.

5) Titanium alloy springs with optimum tensile strength and coating by Ni-P electroless plating or $\mathrm{Ni}-\mathrm{P}+\mathrm{Au}-\mathrm{Ni}$ electroless plating in comparison with steel springs lead to a 13 percent decrease in free height and a 57 percent decrease in weight.
\end{abstract}

Key Words : Titanium alloy, Valve spring, Fatigue strength, Aging, Wear resistant coating, Motoring test

\section{1.はじめに}

エンジンの出力，燃費に大きな影響を与える動弁系に対 しては慣性重量の低減が最も重要で, 個々の部品の軽量化 が盛んに研究されている。次世代の弁ばね用材料として, チ夕ン合金は鋼に比べ比重が小さく低弾性率で比強度が高 いため，大幅な軽量化が達成できるばね材料として有望視 されてきた ${ }^{1)}$ 。しかし，チタン合金の疲労強度へ大きな影 響を及ぼす伸線や時效処理の詳細が明らかではなく、ばね としての最適製造条件が知られてはいない。また，チタン 合金は耐摩耗性が著しく悪く, 使用時にばね線間, 及び座 面部が激しく摩耗し，ばね定数の低下や折損を引き起こす ことがチタン合金製弁ばねの実用化の大きな課題となって いる。そこで，チタン合金の疲労強度に及ほす時効条件の 影響を詳細に調查し，さらに，各種表面処理膜のチタン合 金に対する耐摩耗向上効果を研究した。その結果，ばねと しての最適製造条件と耐摩耗性の優れた表面処理膜が見い 出され，大幅な軽量化とコンパクト化が達成されるチタン 合金製弁ばねの開発ができた。

\section{2. 機械的特性}

\section{$2.1 \beta$ 型チタン合金}

$\beta$ 型チタン合金には歴史のある Ti-13V-11Cr-3Al から $\beta \mathrm{C}(\mathrm{Ti}-3 \mathrm{Al}-8 \mathrm{~V}-6 \mathrm{Cr}-4 \mathrm{Mo}-4 \mathrm{Zr})$ など比較的新しいものまで 多くの種類がある。しかし， $\beta$ 型合金の自動車部品への適 用例は少なく，現在でも十分な材料選択がなされていると は思われない。また， $\beta$ 型合金の機械的性質には溶解から 伸線まで製造工程の厳密な管理が必要と言われている。

このような背景から，弁ばね用の $\beta$ 型合金を評価するに あたり，最も歴史があり製造条件も安定していて，さらに， 伸線加工と時効処理を組み合わせることで高い強度のでる Ti-13V-11Cr-3Al を評価材として選択した。Table 1 に実験 に用いた Ti-13V-11Cr-3Al 合金の化学成分を示す。

Fig. 1 に伸線加工率を $80 \%$ とした線径 $\phi 3.95 \mathrm{~mm}$ の線材 を, $673 \mathrm{~K}$ から $823 \mathrm{~K}$ まで時効処理温度を変えた場合の引 張強さと伸びへ及ぼす時効時間の影響を示す。引張強さは 時効温度 673〜 723Kでは時効時間と共に増加を続け，15h では $1850 \mathrm{MPa} も の$ の值に達することがわかる。さらに，伸び についてみると，この時効条件に扔いても $10 \%$ 程度の延性

原稿受付日 1995 年9月25日

* ばね技術研究会1995年度春季講演会にて発表

**日本発条 (株) (NHK Spring Co., Ltd.) 
を維持している。一方，時効温度の高い $773 \mathrm{~K}$ および 823 $\mathrm{K}$ においては，過時効のため引張強さは低下していて，伸 びについても低下するという傾向が認められる。

\section{2 疲労強度}

\section{2 .1 線材の疲労強度}

疲労強度へ及ぼす各種時効条件の影響を中村式回転曲げ 疲労試験によって調べた。試験片は $80 \%$ の冷間伸線により 線径 $\phi 3.95 \mathrm{~mm}$ とした線材である。時効条件は, 引張強さ がほほピークとなる時効条件の $698 \mathrm{~K} て ゙ ~ 15 \mathrm{~h}$ 及び過時効と なる $773 \mathrm{~K}$ で $2.5 \mathrm{~h}$ ，さらに高温の $823 \mathrm{~K}$ で $2.5 \mathrm{~h}$ のものと した。なお, 試験片には時効後, 疲労強度向上を目的とし てショットピーニングを行った。Fig. 2 に疲労試験結果を 示す。図中の引張強さがピークとなる時効条件 $698 \mathrm{~K}$ は折

Table 1 Chemical compositions of titanium alloy

\begin{tabular}{|c|c|c|c|c|c|c|c|}
\hline \multicolumn{9}{|c|}{ Chemical compositions } & \multicolumn{1}{c|}{$w t \%$} \\
\hline$V$ & $\mathrm{Cr}$ & $\mathrm{Al}$ & $\mathrm{Fe}$ & 0 & $\mathrm{~N}$ & $\mathrm{C}$ & $\mathrm{Ti}$ \\
\hline 12.5 & 10.0 & $\begin{array}{c}2.5 \\
\sim\end{array}$ & $\max$. & $\max$. & $\max$. & $\max$. & \\
$\sim$ & $\sim$ & $\sim$ & 0.35 & 0.17 & 0.05 & 0.05 & Rem. \\
14.5 & 12.0 & 3.5 & & & & & \\
\hline
\end{tabular}

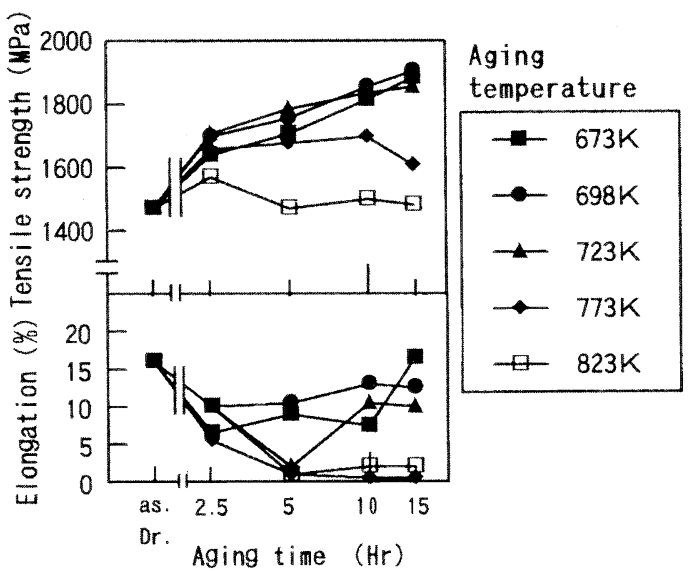

Fig.1 Relationship between aging conditions and mechanical properties in $13-11-3$
損データをバンドで示し, 最も過時効となる $823 \mathrm{~K}$ の条件 については折損データの下限を実線で示してある。疲労強 度は時効温度の高いほど, すなわち引張強さの低いほど高 い傾向が明りょうに認められる。この疲労強度の材料強度 依存性は一般の鋼とは逆であり，興味深い現象である。

Fig. 3 に疲労強度の高い $823 \mathrm{~K}$ と疲労強度の低い $698 \mathrm{~K}$ の場合のX線応力測定法による残留応力分布を示す。両者 ともにショットピーニングによって大きな圧縮残留応力場 が表面に形成されていることがわかる。しかし，その分布 の大きさや深さについては両者間に大きな差異は認められ ず，残留応力からは疲労強度の差の説明はできない。

Fig. 4 に折損したサンプルの破面写真の一例を，また， Fig. 5 に内部起点の起点寸法と時効温度の関係をそれぞれ 示す。なお, 起点寸法は起点の最大寸法としている。起点 寸法は時効温度が高くなるほど小さくなる傾向を示してお り，時効温度の高いほうが久陷サイズが小さくなって，同 じ残留応力分布でも疲労強度が高くなるものと思われる。 また，起点部には介在物等は見られず，析出 $\alpha$ 相内，また は析出 $\alpha$ 相と $\beta$ 相の界面からの微視割れ起点と思われるも のが見られる

\section{2 .2 コイルばねの疲労強度}

Fig. 6 は線径 $\phi 3.95 \mathrm{~mm}$, コイル平均径 $23.05 \mathrm{~mm}$, 有効巻 き数 3.5 のコイルばねの疲労寿命と引張強さの関係を示した ものである。試験応力条件は $490 \pm 392 \mathrm{MPa}$ と $490 \pm 343 \mathrm{MPa}$

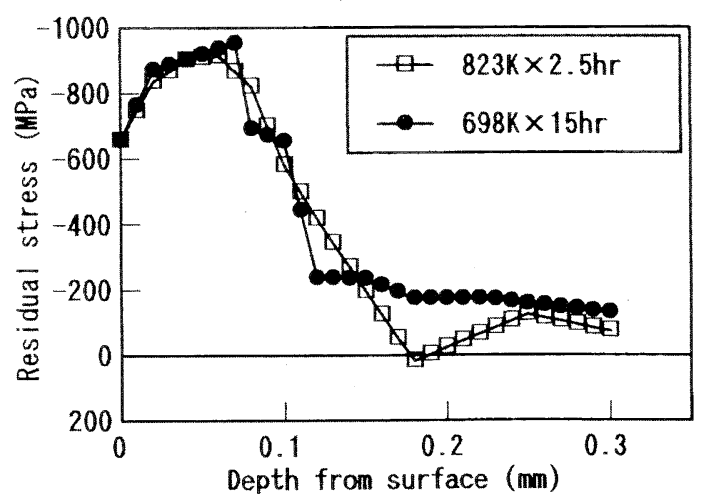

Fig. 3 Distribution of residual stress

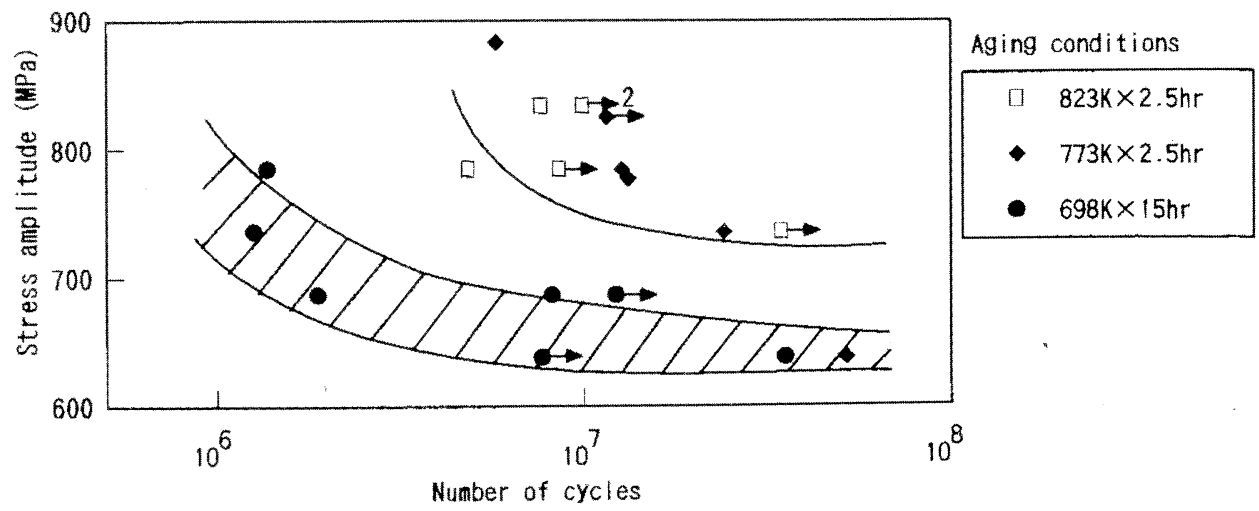

Fig. 2 Effects of tensile strength on fatigue strength 
の 2 条件で，ばねには線材と同様にショットピーニングが 施してある。コイルばねにおいても疲労寿命は引張強さが 低くなると共に明らかに増加し, 線材での疲労強度と同様 の材料強度依存性を示している。また、490土392MPaにお いても引張強さを $1470 \mathrm{MPa}$ とれば繰返し数 $10^{7}$ 回の優れた 寿命を示すことがわかる。

\section{3 へたり性}

疲労強度と同様にへたり性（クリープ）は，ばねにとっ て重要な特性である。Fig. 7 は Fig. 6 の疲労試験に供したば ねと同一のばねに大気中 $403 \mathrm{~K}$ 雾囲気で締付け試験を行っ

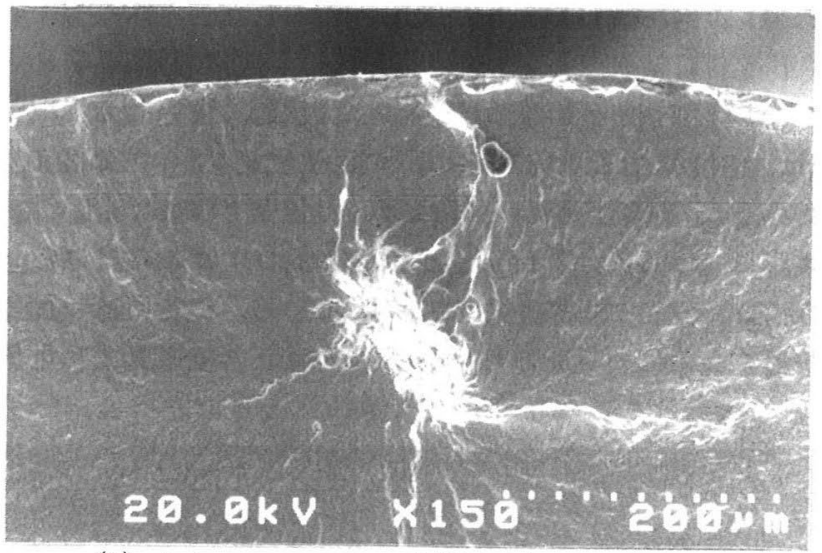

(1) Aging temperature : 698K Origin size : $154 \mu \mathrm{m}$

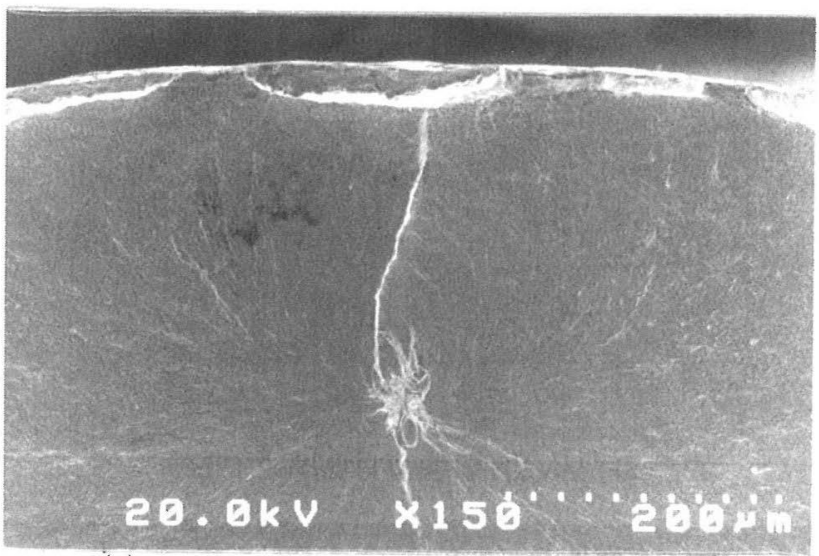

(2) Aging temperature : $773 \mathrm{~K}$ Origin size : $46 \mu \mathrm{m}$

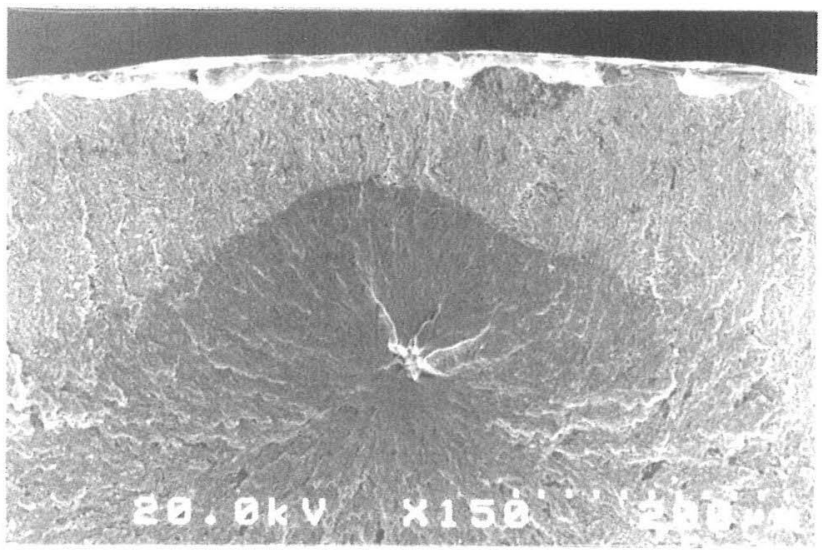

(3) Aging temperature : $823 \mathrm{~K}$ Origin size : $30 \mu \mathrm{m}$

Fig. 4 SEM observation of fractured surface by rotary bending test
た結果を示したものである。締付け応力はワールの応力修 正係数を考慮して $882 \mathrm{MPa}$ (考慮しない場合 $700 \mathrm{MPa}$ ) で, 締付け時間は $144 \mathrm{~h}$ である。へたり量（残留せん断ひずみ） は一般の鋼と同様に引張強さの増加とともに小さくなるこ とがわかる。したがって，へたり性を向上させるためには 引張強さをあげる必要があるが, 疲労強度の維持を考慮す れば限界がある。そこで，Fig. 7 中の SWOSC の高強度材 $\left(\sigma_{\mathrm{B}}=2059 \mathrm{MPa}\right)$ のへたりのレベルより優れた耐へたり性 を示すチタン合金（13-11-3）の引張強さを読みとると，は るかに強度の低い $\sigma_{\mathrm{B}}=1520 \mathrm{MPa}$ 以上である。この引張強 さは Fig. 6 の疲労強度において十分な寿命を示すことがわ かる。

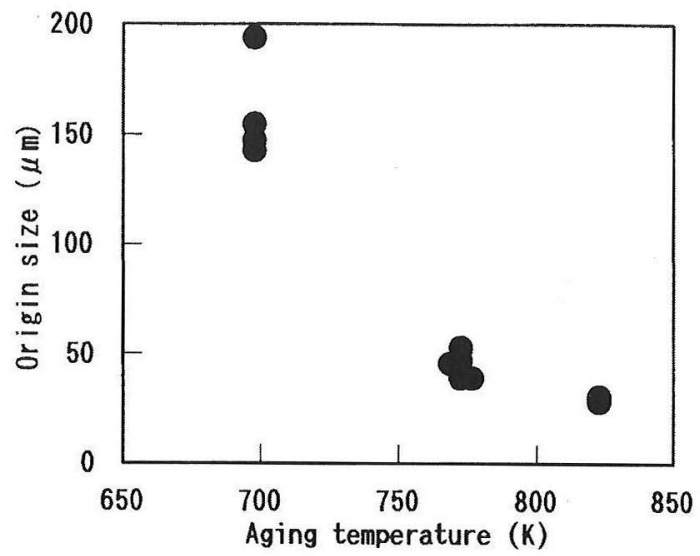

Fig. 5 Relationship between aging temperature and origin size

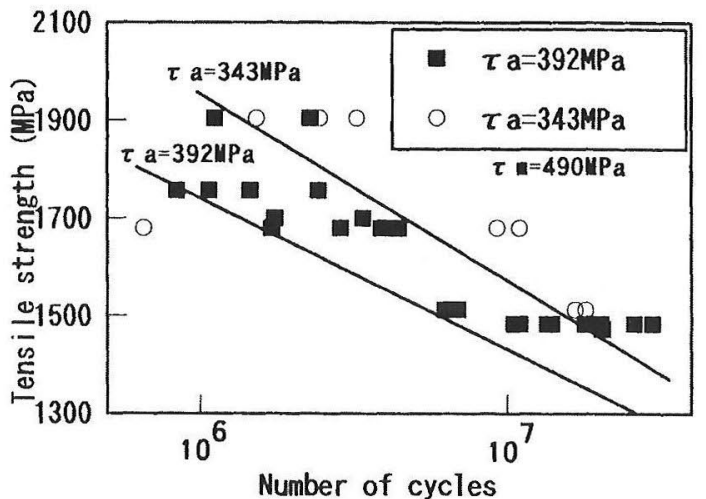

Fig. 6 Effects of tensile strength on coil spring fatigue strength

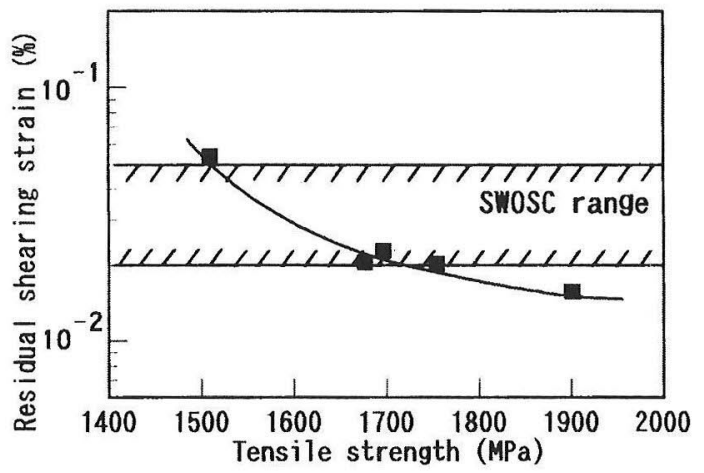

Fig. 7 Effects of tensile strength on residual shearing strain 


\section{4 摩耗防止膜}

\subsection{1 耐摩耗表面処理の選択}

チタン合金の耐摩耗表面処理としては Mo の溶射や CrN のイオンプレーティング膜， Ni-P 合金めっき膜などが報告 されている。このうち Mo の溶射膜は一般に面粗度が大き く，ばね用としては適当でないと判断される。また，イオ ンプレーティング膜や耐摩耗 Ni-P 膜についてはその種類も 多い。そこで, ピンノブロック摩擦摩耗試験によって耐摩 耗膜の選択を行った。

ピンノブロック摩擦摩耗試験の模式図は Fig. 8 に示され るが，一定速度で回転するピンにV 型ブロックを押しつけ ていき, 焼付きの限界荷重の大小によって膜の耐摩耗性を 評価するものである。

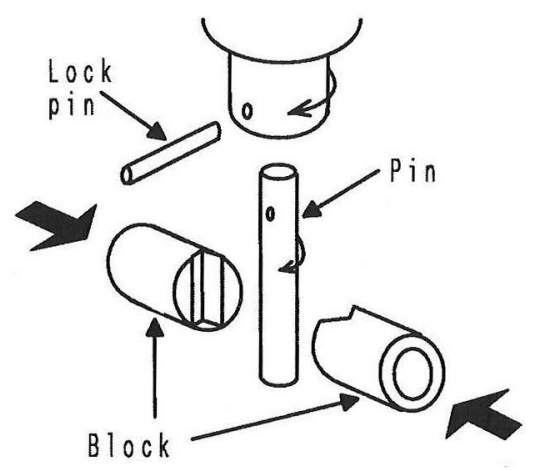

Fig. 8 Mode of pin/block wear test

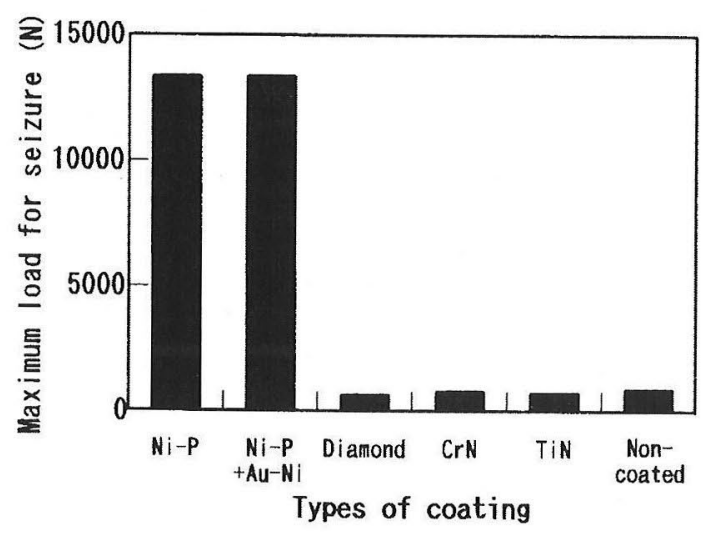

Fig. 9 Results of pin/block wear test

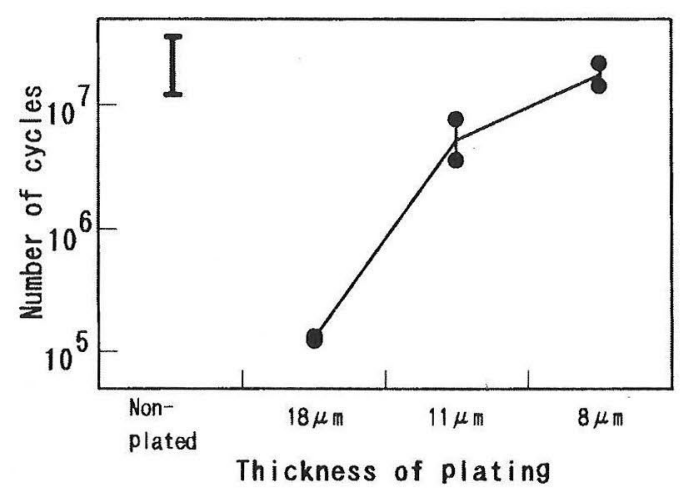

Fig. 10 Relationship between coating conditions and fatigue strength
Fig. 9 に各種の膜と焼付き限界荷重の関係を示す。本試 験ではピンに Ti-15Mo-5Zr-3Al 合金, ブロックに SKH51 を用い, 耐摩耗膜はブロック表面にのみ成膜した。また, 試験は鉱油による潤滑下で行い，摩擦速度は $0.4 \mathrm{~m} / \mathrm{s}$ とした。 付した膜はイオンプレーティング膜として TiN , CrN , ダ イヤモンド, そしてめっき膜として無電解 Ni-P, 無電解 $\mathrm{Ni}-\mathrm{P}+\mathrm{Au}-\mathrm{Ni}$ である。Fig. 9 からイオンプレーティング膜 はいずれも焼付き限界荷重は低く, 未処理のものとほぼ同 等のレベルであることがわかる。一方, 無電解Ni-Pめっき 及び無電解 $\mathrm{Ni}-\mathrm{P}+\mathrm{Au}-\mathrm{Ni}$ めっきは非常に優れた耐摩耗性を 示し, 并ばね用の耐摩耗膜として有効なことがわかる。

\subsection{2 コイルばねへの適用}

Fig. 6 に結果を示すものと同一のばねに無電解 Ni-Pめっ きを膜厚を種々に変えて施し, 疲労試験を行なった。 Fig.10に疲労試験結果を示す。試験応力条件は $490 \pm$ $392 \mathrm{MPa}$, 試験に用いたばね材の引張強さは $1470 \mathrm{MPa}$ で, 膜厚は 8,11 及び $18 \mu \mathrm{m}$ とした。また，ばねにはめっき 後にショットピーニングが施されている。痩労寿命は膜厚 が薄くなるほど長くなり, $8 \mu \mathrm{m}$ ではめっきなしのものと同

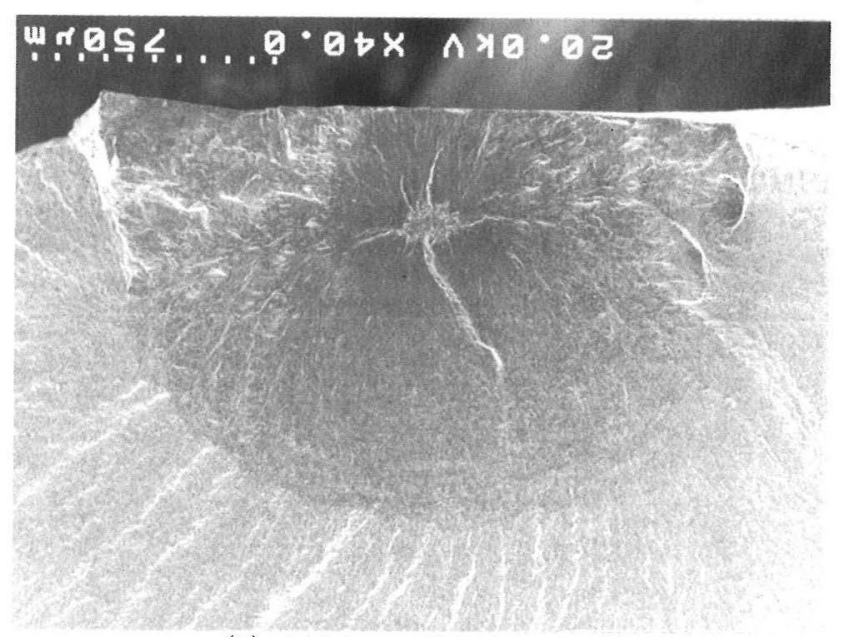

(1) Thickness of plating : $8 \mu \mathrm{m}$

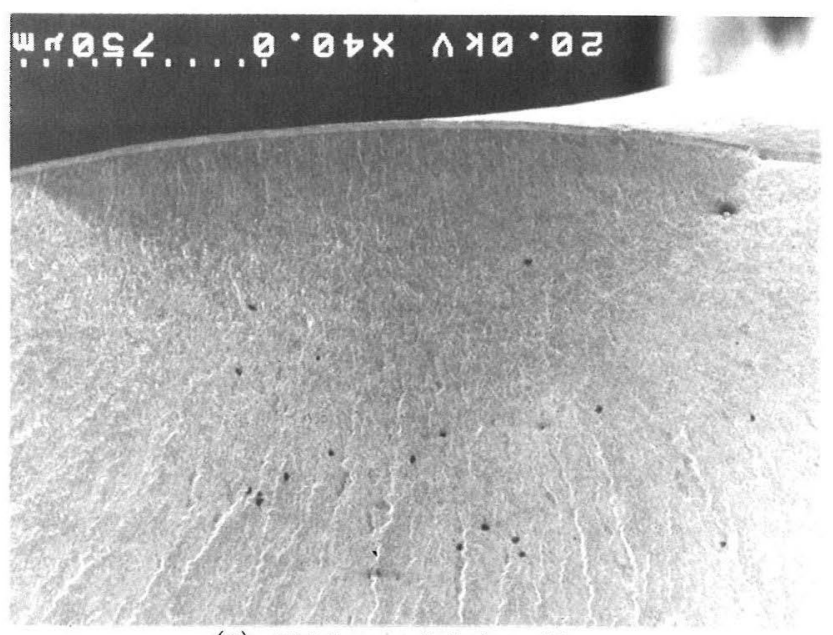

(2) Thickness of plating: $18 \mu \mathrm{m}$

Fig. 11 SEM observation of fractured surface of coil spring coated by $\mathrm{Ni}-\mathrm{P}$ electroless plating 
等の疲労強度を得ることができた。

また, Fig. 11 に膜厚 $8 \mu \mathrm{m}$ と $18 \mu \mathrm{m}$ の折損したサンプル の破面写真を示す。これらのばねの折損起点は, 膜厚 $8 \mu \mathrm{m}$ ではチタン合金内部からのフィッシュアイ状のものであり, 膜厚 $18 \mu \mathrm{m}$ ではめっき膜に生じた表面のき裂であった。こ のことから, 膜厚が厚いとめっき膜のき裂によるノッチ効 果, 及び圧縮残留応力が深部まで付与されにくいことによ りばねの表面が起点となり，膜厚が薄いとチタン合金内部 での微視割れが起点になるものと思われる

\section{5 エンジン耐久}

現行の鋼製の弁ばねとばね定数，取付時および弁開時荷 重を同一にしたチタン合金（13-11-3）ばねを用い，モー タリング耐久試験によって耐久性, 耐摩耗性及び荷重損失 を調べた。耐摩耗膜としては無電解 Ni-P及び無電解Ni-P+ $\mathrm{Au}-\mathrm{Ni}$ 膜とした。耐久試験の条件は并開時応力 $583 \mathrm{MPa}$ ，取 付時応力 $244 \mathrm{MPa}$ ，そしてエンジン回転数6500rpm，耐久時 間 600 h である。

Fig. 12 に摩耗量（試験中のばね重量变化）と時間の関係 を示す。比較材の摩耗防止膜のないばねではわずか $5 \mathrm{~h}$ の 試験において $0.09 \mathrm{~g} も の$ 摩耗を生じていることがわかる。 しかし, 無電解 Ni-P及び無電解 $\mathrm{Ni}-\mathrm{P}+\mathrm{Au}-\mathrm{Ni}$ 膜を成膜し

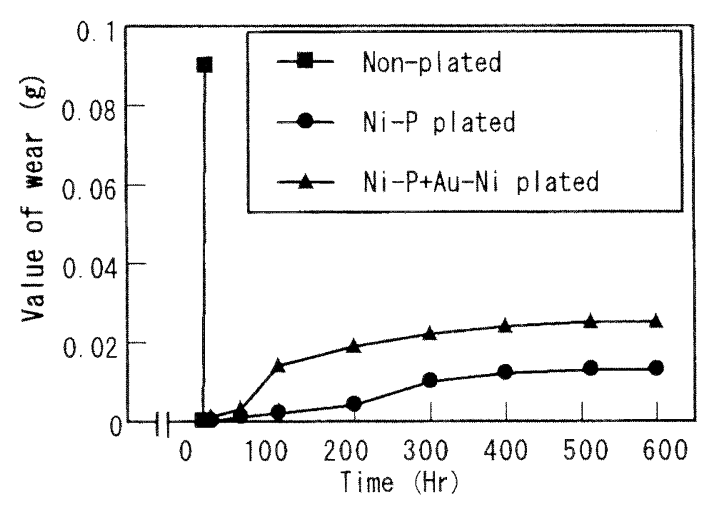

Fig. 12 Value of wear in motoring test

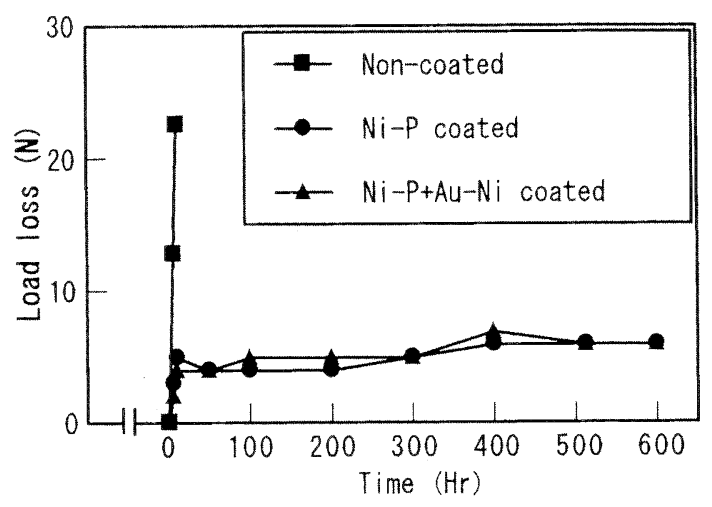

Fig. 13 Load loss in motoring test
たばねは耐久時間 $600 \mathrm{~h}$ において折損することもなく，ま た，摩耗減量も $0.03 \mathrm{~g}$ 以下で飽和する傾向にあり実用性の あることがわかる。

Fig. 13 に耐久時間と荷重損失の関係を示す。比較材は 5 $\mathrm{h}$ で $22.6 \mathrm{~N}$ の荷重損失を生じているのに対し, 無電解

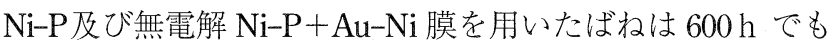
$10 \mathrm{~N}$ 以下の荷重損失に押さえられており，へたり性に関し ても実用上問題のないレベルとなっている。

\section{3. チタン合金ばねの効果}

チタン合金ばねを，現行の鋼（SWOSC）ばねとばね定 数，コイル外径及び最大たわみ量を同一にして設計した場 合の設計例を Table 2 に示す。この設計例では鋼のばねに 対しチタン合金のばねは自由高さで $13 \%$ 減，重量で $57 \%$ 減ものコンパクトで軽量なばねが期待されることがわか る。

Table 2 Example of design of compression coil spring

\begin{tabular}{|c|c|c|c|c|c|l|}
\hline Materials & $\begin{array}{c}\text { Dia. } \\
\text { of } \\
\text { wire } \\
(\mathrm{mm})\end{array}$ & $\begin{array}{c}\text { Spring } \\
\text { rate } \\
(\mathrm{N} / \mathrm{mm})\end{array}$ & $\begin{array}{l}\text { Outside } \\
\text { dia. of } \\
\text { coil } \\
(\mathrm{mm})\end{array}$ & $\begin{array}{c}\text { Maximum } \\
\text { deflection }\end{array}$ & $\begin{array}{c}\text { Free } \\
\text { height }\end{array}$ & Weight \\
\hline SwOSC & 4.2 & 7.6 & 43.0 & 66 & 103 & 118 \\
\hline $13-11-3$ & 4.3 & 7.6 & 43.0 & 66 & 90 & 51 \\
\hline Effect & - & - & - & - & $13 \%$ down & $57 \%$ down \\
\hline
\end{tabular}

\section{4. まとめ}

（1） $\beta$ 型合金 Ti-13V-11Cr-3Al の疲労強度は鋼とは逆の 材料強度依存性が認められる。

（2）へたり性は引張強さが大きいほど優れるが, 鋼と比 較するとより低強度でも同等のへたり性を示す。

(3) 耐摩耗膜としては無電解 Ni-P 及び無電解 Ni-P+ $\mathrm{Au}-\mathrm{Ni}$ 膜が優れている。

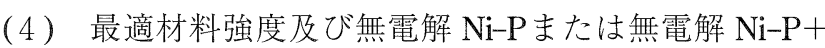
Au-Niめっき膜を用いたばねはモータリング試験に 耐え，実用性のあるチタン合金製弁ばねであること がわかった。

（5）最適材料強度及び無電解 Ni-Pまたは無電解 Ni-P+ $\mathrm{Au}-\mathrm{Ni}$ めっき膜を用いたチタン合金製弁ばねにより， 鋼のばねに対し自由高さで $13 \%$ 減，重量で $57 \%$ 減 ものコンパクトで軽量なばねが期待される。

\section{参考文献}

1) Murakami, A. Hagiwara, Y., Igarasi, T., Ozone, T., Matsuhashi,K.and Hayashi, H., SAE Technical Paper Series, No. 890470, 1989.

2）梅澤修，長井寿，石川圭介，鉄と鋼，76-6（1990）,924。 